\title{
LACCO SOCIAL, TEMPORALIDADE E DISCURSO: DO TOTEM E TABU AO DISCURSO CAPITALISTA
}

Fabio Malcher e Ana Beatriz Freire

Fabio Malcher
Doutorando em
Teoria Psicanalítica
pelo Instituto de
Psicologia da UFRJ.
Participante do
projeto de pesquisa
“Circulando e
traçando laços
e parcerias:
atendimento para
jovens autistas e
psicóticos”, na
UFRJ.
Ana Beatriz Freire
Psicanalista.
Professora titular
do Programa de
Pós-graduação em
Teoria Psicanalítica
do Instituto de
Psicologia da UFRJ.
Correspondente da
Escola Brasileira de
Psicanálise/Seção
RJ. Pesquisadora do
CNPq.

Fabio Malcher

Doutorando em

Teoria Psicanalítica pelo Instituto de Psicologia da UFRJ. Participante do projeto de pesquisa "Circulando e traçando laço e parcerias: atendimento par jovens autistas e psicóticos", na Ana Beatriz Freire Psicanalista. Professora titular do Programa de Pós-graduação em Teoria Psicanalítica do Instituto de Psicologia da UFRJ. Correspondente da Escola Brasileira de RJ. Pesquisadora do

RESUMO: Para refletir sobre certas peculiaridades contemporâneas do laço social, a temporalidade lógica em jogo no laço social é abordada a partir de uma articulação entre o mito freudiano de Totem e tabu e o sofisma lacaniano O tempo lógico e a asserção de certeza antecipada, ressaltando-se a necessidade de uma escansão temporal com função significante ao laço social. A mutação do discurso do mestre ao discurso do capitalista astuciosamente faz com que a escansão significante evite o nível do impossível, da impotência ou a separação pela barra, ligando $S_{1}$ diretamente a $S_{2}$, afetando a temporalidade lógica, e, consequentemente, o laço social.

Palavras-chave: Psicanálise, laço social, temporalidade, capitalismo, gozo.

ABSTRACT: Social bond, temporality and discourse: from Totem and taboo to the capitalist discourse. In order to reflect on certain contemporary peculiarities of the social bond, the logical temporality at stake regarding the social bond is addressed from an articulation between the Freudian myth of Totem and taboo and the Lacanian sophism The logical time and the assertion of anticipated certainty, highlighting the need of a temporal scansion with significant function to establish the social bond. The mutation of the master's discourse into the capitalist discourse cunningly makes the significant scansion avoid the impossible and the impotence levels, as much as the separation imposed by the bar, directly tying $S_{1}$ to $S_{2}$, affecting the logical temporality and, consequently, the social bond.

Keywords: Psychoanalysis, social bond, temporality, capitalism, jouissance.

DOI - http://dx.doi.org/10.1590/S1516-14982016000100005 


\section{INTRODUÇÃO}

O laço social é um vasto e profícuo campo de pesquisa, que convoca a psicanálise a um trabalho contínuo, na medida em que as mudanças na estrutura de gozo da cultura afetam-no diretamente, como demonstra a teoria lacaniana dos discursos. O laço social vem sofrendo impactos a partir do advento do capitalismo, em sua aliança com a ciência, incitando uma reflexão acerca de certos aspectos discursivos contemporâneos. No presente artigo, o aspecto a ser explorado é o efeito que a mutação do discurso do mestre ao discurso do capitalista opera na temporalidade lógica em jogo no laço social.

Para localizar a temporalidade implicada no laço social, propomos uma articulação entre o mito freudiano elaborado em Totem e tabu (FREUD, 1912-1913/2012) acerca da origem do laço social e o sofisma lacaniano O tempo lógico e a asserção de certeza antecipada (LACAN, 1945/1998). Essa articulação visa destacar a temporalidade lógica implicada no laço social, a saber, a necessidade de uma escansão temporal com função significante que delimite um tempo para compreender entre o instante do olhar e o momento de concluir, escansão que ocasione a emersão do sujeito como dividido e a queda do objeto a.

O discurso inaugurado pela superação da horda primeva opera como discurso do mestre, no qual a escansão significante $\mathrm{S}_{1}-\mathrm{S}_{2}$ ocupa o nível do impossível. Nesse discurso, demarca-se a impossibilidade de o sujeito ser plenamente representado por um significante junto a outro significante. Mesmo ligados por uma seta, permanece um impossível em jogo na relação $\mathrm{S}_{1}-\mathrm{S}_{2}$. Nas três outras modalidades discursivas propostas por Lacan em $O$ avesso (LACAN, 1969-1970/1992), $S_{1}$ e $S_{2}$ ficam apartados, seja pela barra — nos discursos universitário e da histérica —, seja pela barreira da impotência — no discurso do analista. Essa separação sofre efeitos no discurso do capitalista, proposto por Lacan em 1972, no qual $\mathrm{S}_{1}$ passa a se ligar diretamente a $\mathrm{S}_{2}$. Como pensar a temporalidade lógica nesse discurso? Quais seus efeitos no laço social?

O presente artigo não tem a pretensão de responder plenamente a tais questões, o que, entretanto, não nos desencoraja na tentativa de melhor localizar os aspectos estruturais que as perpassam. Para tal, cumpre desenvolver a hipótese de uma condição de ordem temporal ao laço social, para, em seguida, localizar essa questão no discurso do mestre e, finalmente, no discurso do capitalista.

\section{TOTEM E TABU E A CERTEZA ANTECIPADA}

A construção de Freud acerca da origem do laço entre os homens tem seu maior desenvolvimento no ensaio Totem e tabu. A superação da horda primeva pelo totemismo representa uma mudança de paradigma que demarca um corte que origina o laço social. Na horda primeva, o pai primevo, líder da horda, concentra 
para si toda a satisfação sexual e agressiva, exercendo um monopólio de gozo de maneira tirânica. Único a ter acesso a todas as fêmeas da horda, interditando-o aos demais machos, coibindo com violência suas tentativas e expulsando-os à medida que estes crescem e o desafiam, o pai primevo vivencia os impulsos de modo desinibido, sem estabelecer laço com os demais membros da horda. Dessa forma, fica evidente que a possibilidade de mudança de paradigma passa, necessariamente, pela eliminação dessa figura central. Acompanhar o destino do pai primevo constitui, assim, uma interessante via para explorar a origem do laço social.

Em Totem e tabu, Freud destaca três relações muito permeadas de tabu, com os soberanos, os inimigos, e os mortos, insígnias que atribuímos o pai primevo (MALCHER \& FREIRE, 2013). No lugar de soberano, ou líder, o pai primevo exerce sua lei de forma caprichosa e com base na força bruta. O mais essencial no lugar de líder é o caráter de exceção que tal lugar acarreta, na medida em que "[...] a exigência de igualdade vale apenas para os indivíduos, não para o líder." (FREUD, 1921/2011, p.83). Além de não se submeter a qualquer lei, o líder da horda interdita a satisfação pulsional aos demais concorrentes, constituindo-se como uma constante fonte de insatisfação, o que o faz figurar como inimigo. Ao passo que o líder não estabelecia laço por viver impulsos desinibidos, seu monopólio sexual e da agressividade resulta na inibição dos impulsos dos demais, o que tende a favorecer um perigoso laço entre os insatisfeitos.

Configura-se uma situação irônica: aquele que não faz laço favorece o laço; laço marcado de tonalidades de rancor ao inimigo que os interdita o gozo. É importante ressaltar que esse laço inicial entre os insatisfeitos ainda não se configura como laço social, sendo preciso algo mais para tal. No entanto, esse esboço de laço é suficiente para sustentar uma reunião com claro objetivo: eliminar o líder que se tornou inimigo. Este objetivo se erige sobre uma causa maior, o acesso sexual às fêmeas da horda, um acesso ao suposto gozo que cabia ao pai primevo. Temos as vertentes de pulsão sexual e de morte inibidas pelo pai primevo e que insistem na busca de satisfação.

Se, individualmente, os vencidos e expulsos pelo pai primevo não se sentiram fortes o suficiente para enfrentá-lo, reunidos mostraram-se capazes de eliminá-lo. Os filhos insatisfeitos matam o líder e canibalizam seu corpo como forma de obter seu poder, de identificarem-se com ele (FREUD, 1912-1913/2012). A canibalização do corpo do pai primevo indica que o acesso ao gozo junto às fêmeas só é concebido a partir do lugar do líder, parecendo imprescindível a identificação àquele que ocupava o lugar de exceção, lugar que conduziu ao de inimigo, chegando-se à insígnia final, morto.

Acerca das três insígnias destacadas, Freud afirma: "Sabemos que os mortos são soberanos poderosos; talvez nos surpreendamos ao saber que são vistos como 
inimigos." (idem, p.89, grifos nossos). Talvez essa articulação soe menos surpreendente a partir do que acompanhamos acerca do destino fatal do pai primevo, delineando-se um desdobramento lógico entre as insígnias de soberano, inimigo e morto.

O desdobramento até a insígnia de morto não é suficiente para que o laço entre os insatisfeitos se configure enquanto laço social, embora represente uma abertura de oportunidade para tal. O momento em que os vencedores, bocas e mãos banhadas de sangue, abandonam a carcaça do outrora temido e admirado líder e se voltam para as fêmeas da horda, configura-se como crucial, com duas possibilidades de destino à horda primeva: continuação ou corte; há uma decisão em jogo. Momento capital.

Nossa hipótese acerca de uma condição de ordem temporal ao laço social se ancora naquilo que pode operar como corte na continuação da horda primeva, o que nos conduz ao sofisma proposto por Lacan em O tempo lógico e a asserção de certeza antecipada acerca do desdobramento de três tempos lógicos em determinada tomada de decisão. Erik Porge considera esse escrito como uma verdadeira invenção de Lacan, com valor de ato (PORGE, 1989/1994), já que um ato se refere à determinação de um começo. É por esse viés que articularmos este sofisma ao mito freudiano, por ambos tratarem de um começo que se determina em ato.

O sofisma tem início em um problema de lógica a partir de uma proposta elaborada pelo diretor de uma prisão a três presos (LACAN, 1945/1998), Outro que dita as leis que regem a lógica do problema, as balizas significantes do problema. Cada um terá afixado às suas costas um disco branco ou preto, podendo ver o disco do outro, mas não o seu próprio. Eles sabem que há cinco discos disponíveis a serem distribuídos, dois pretos e três brancos: • ○૦૦. Assim que algum deles deduza a cor de seu disco, deve anunciá-la e, ao justificar de maneira lógica sua dedução, será libertado.

Os três presos, A, B e C, recebem discos brancos, ficando os dois discos pretos excluídos, delineando-se o desenrolar lógico da situação. Certamente o caso mais simples e imediato seria o de ver dois discos pretos, pois a certeza de ter o disco branco se imporia: $\bullet \rightarrow$. Esse é o único caso em que uma certeza se impõe a partir de um dado visível, único caso em que se pode chegar a uma certeza diretamente do instante do olhar. Ao ver dois discos brancos, cada preso sabe que essa certeza imediata está excluída, havendo uma primeira pausa; o instante do olhar não basta.

Para tratar desse problema de lógica é preciso se colocar na posição de um dos presos, A, que adota a hipótese de seu próprio disco ser preto e tenta se colocar no lugar de B, conjeturando sobre o raciocínio lógico deste. O preso B veria nessa hipótese que A aventa acerca de seu próprio disco ser preto - um disco 
preto (A) e um disco branco (C); o instante do olhar ainda não é suficiente para gerar uma certeza, já que $\mathrm{\bullet} \rightarrow \mathrm{O}$ ou $\mathrm{O}$.

O passo seguinte consiste em A, em sua suposição de que seu próprio disco seja preto, colocar-se no lugar de B e assumir como hipótese de que seu disco (B) seja preto. Embora saiba que o disco de B não é preto, já que ele vê que B e C têm discos brancos, essa suposição é importante para tentar dar sentido ao movimento de B, que ainda permanece parado como os demais. Nesse cenário hipotético, $\mathrm{C}$ veria dois discos pretos e teria a certeza imediata de possuir um disco branco: • $\rightarrow$ O. Logo, B teria na hesitação de C um indício seguro de que seu disco não é preto, e se dirigiria à saída. Na medida em que nenhum dos presos se movimenta, A entende que seu próprio disco deve ser branco, pois, caso fosse preto, B já deveria ter se dirigido à saída diante da hesitação de C.

Em uma situação definida de maneira lógica, sendo todos os discos brancos, as mesmas conclusões podem ser atribuídas aos três presos, sendo lícito supor uma procura simultânea pela saída, o que gera uma segunda pausa. Essa segunda escansão se dá pelo fato de cada um duvidar de sua própria conclusão, já que esta era baseada na hesitação dos demais. Lembramos que a decisão acerca da cor do disco deve ser justificada com argumentos lógicos à saída.

Essa segunda escansão é essencial, alterando a situação de maneira definitiva, sem mais espaço para dúvida. A certeza advém da própria escansão, na medida em que não haveria motivo para parada se um deles houvesse deduzido a cor de seu disco a partir da visão de um disco preto. Se todos recuam diante do movimento dos demais, essa escansão implica a conclusão definitiva de que todos têm o disco branco. O que se destaca é que a explicação lógica ao diretor à saída não consegue se justificar somente em palavras, pois é somente pelo ato que a asserção subjetiva de certeza antecipada se estabelece, articulando-se a dimensão subjetiva ao ato. Como articulamos esse sofisma e a superação da horda primeva?

Voltemos ao momento em que os insatisfeitos eliminaram o líder/inimigo e canibalizaram seu corpo. Sua eliminação tinha como objetivo o acesso ao gozo pleno junto às fêmeas, e, estando o pai primevo morto e devorado, tal acesso fica franqueado. Contudo, por se tratar de uma situação que envolve vencedores, e não somente um vencedor que tenha desafiado e superado o antigo líder, configura-se um impasse, pois o lugar de exceção é único. Ao se voltarem às fêmeas, percebem-se rivais, o que pode ocasionar uma primeira parada na iminência de um novo combate pelo posto do pai primevo. Após os urros e grunhidos que permearam a eliminação e deglutição do corpo do pai primevo, a gritaria pode seguir em nova disputa pelo monopólio do gozo, ou pode haver um átimo de silêncio em que os olhares se cruzem, medindo-se uns aos outros, dando algum espaço para a reflexão acerca do destino da horda. É o momento de se decidir acerca da continuidade ou do corte. 
Caso uma nova disputa se estabeleça, gerando um novo líder, o pai primevo estaria redivivo, exceção que exerce o monopólio do gozo, produzindo uma maioria insatisfeita; a horda primeva segue presente. A mudança de paradigma pressupõe um corte nesse presente maciço, sem escansão temporal.

O silêncio que pode surgir entre a eliminação do pai primevo e a decisão acerca de lutar ou não por seu lugar é fundamental. Nesse momento, há uma primeira parada que denuncia o impasse. São vários vencedores e o acesso ao gozo somente é concebido pela via da exceção. Essa primeira parada se refere ao instante do olhar diante de um impasse. Os olhares dos vencedores se medem e avaliam o novo embate em eminência, situando-se à beira de nova disputa pelo monopólio do gozo. Ao se esboçar um movimento em direção à luta entre eles pode haver uma segunda e crucial parada, na qual o destino fatal do pai primevo se alça como futuro inevitável àquele que vencer a disputa e ocupar o lugar de exceção: morte e despedaçamento do corpo.

A primeira parada possibilita que do instante do olhar se entre no tempo para compreender, tempo lógico que só pode ser confirmado, retroativamente, pela segunda escansão, demarcando a passagem do tempo para compreender para o momento de concluir: "Passado o tempo para compreender o momento de concluir, é o momento de concluir o tempo para compreender" (p.206). Logo, o tempo para compreender se constitui entre as duas escansões temporais, produzindo uma certeza antecipada acerca do impossível que o gozo suposto ao pai primevo comporta, acarretando o momento de concluir: Isso tem que parar!

Sem a segunda parada, do instante do olhar vai-se diretamente ao momento de concluir pela disputa pelo lugar de exceção, não ocorrendo o tempo para compreender o impossível inerente a tal decisão. A ausência desse tempo lógico intermediário parece operar como uma holófrase, elidindo a escansão necessária para que a diferença no paradigma da horda primeva surja, não se tornando a eliminação do líder um parricídio.

A partir da operação do tempo para compreender, a conclusão pode ser diferente alterando o paradigma da horda primeva, renunciando-se ao lugar de exceção, pois somente assim "Eles excluem uma repetição do destino do pai" (FREUD, 1912-1913/2012, p.222). O objetivo de ocupar o lugar do pai primevo “[ [... tinha que ficar insatisfeito. Ninguém mais podia nem era capaz de alcançar a plenitude de poder do pai, a que todos haviam aspirado." (idem, p.226, grifo nosso). A renúncia ao gozo se coloca em primeiro plano.

Há três possibilidades a partir da estruturação do sofisma: ○○○. A insatisfação pulsional imposta pelo pai primevo também gera três possibilidades: a) um único membro insatisfeito desafia o pai primevo e o supera, tomando seu lugar, b) um grupo se reúne e o elimina, depois luta entre si, com um único vencedor ocupando seu posto, ou c) um grupo elimina o pai pri- 
mevo, mas decide que ninguém deve ocupar seu lugar. Se os dois discos pretos entrassem no sistema, a decisão seria imediata por parte do preso que os visse, sabendo ter um disco branco por ser a exceção no sistema: $\bullet \bullet \bullet$. Este parece ser o caso de um único desafiante superar o pai primevo e herdar seu lugar de forma imediata. Se ao menos um fosse preto, uma primeira parada pela dúvida da cor de seu disco se imporia aos dois presos que o vissem: $\bigcirc \bullet \bullet$ ou $\bigcirc$. Todavia, a hesitação de um deles daria ao outro a certeza de ter o disco branco, já que se seu disco fosse preto o outro já teria concluído pela cor branca de seu disco de forma imediata. Essa situação parece coadunar com o caso em que um grupo vence o pai primevo, gerando uma primeira parada diante do impasse de somente um poder ocupar o lugar de exceção. Sem a segunda moção suspensa, uma ruidosa disputa se estabelece, produzindo um novo vencedor, mantendo o paradigma da horda primeva.

Somente o caso de três discos brancos, ficando os pretos excluídos do sistema, gera o desdobramento lógico de uma segunda escansão que, retroativamente, delimita junto à primeira escansão um tempo para compreender capaz de mudar o destino da horda primeva, sendo justamente a exclusão dos discos pretos do sistema, o que estrutura seu desenrolar lógico, que chega ao momento de concluir que deve haver a renúncia à plenitude de gozo supostamente desfrutada pelo pai primevo, operando um corte. Todos se reconhecem simultaneamente como tendo discos brancos, todos iguais no sistema, não podendo haver exceção, como terá sido o pai primevo, $\exists \mathrm{X} \overline{\Phi X}$. Todos estão na mesma situação, castrados, $\forall \mathrm{X} \Phi \mathrm{X}$.

Nessa mudança de paradigma, a própria dimensão temporal entra em cena, ou seja, futuro e passado se articulam ao presente. Refletir acerca do futuro daquele que insistir em ocupar o lugar de exceção gera uma mudança no presente, com o abandono do funcionamento que vise à plenitude de gozo, um passado que se torna inacessível: terá havido gozo, futuro anterior que permeia o paradigma posterior à horda primeva.

Sendo a renúncia pulsional condição ao laço social, revela-se essencial a operatividade da dimensão temporal na decisão acerca da necessidade de renunciar gozo. Refletir depende da capacidade de inibir a ação, mesmo que momentaneamente. Da reflexão resulta uma conclusão em ato, a decisão pela renúncia ao gozo do pai primevo. No sofisma, a decisão dos presos é um juízo assertivo, com estatuto de ato, pois “todo juízo é essencialmente um ato” (LACAN, 1945/1998, p.208). Concebendo que todo juízo é um ato, relacionamos o juízo assertivo pela renúncia de gozo daqueles que eliminaram o pai primevo com o juízo de atribuição implicado na simbolização primordial, no qual o sujeito ganha significantes, mas perde gozo. Logo, o mito da superação da horda primeva é um mito acerca do próprio encontro com a linguagem, da incidência significante no corpo, do qual surge o sujeito como dividido, $\$$. 
O sofisma do tempo lógico também possibilita interrogar a própria constituição do sujeito pela via do ato, e de um ato que se sustenta em uma temporalidade lógica, tratando, mais do que de uma lógica do tempo, de uma "lógica do ato" (PORGE, 1989/1994, p.84,195). O desenrolar lógico do sofisma começa na estrutura significante estabelecida pelo diretor como Outro, porém, a operatividade significante se efetua pela mútua relação entre significante e tempo, sendo as escansões tanto temporais quanto significantes, escansões que separam o significante no tempo. As escansões temporais ganham caráter significante, podendo o sujeito surgir como efeito da articulação entre elas, um sujeito constituído em ato com o caráter de uma antecipação, revelando-se certa dimensão da pressa, dimensão retomada por Lacan no seminário Mais, ainda ao se referir ao texto do tempo lógico: "Pode-se ler muito bem ali, se se escreve, e não somente se se tem bom ouvido, que, a função da pressa [hâte], já é esse a minúsculo que a tetiza [thètise]" (LACAN, 1972-1973/1985, p.67, colchetes nossos). Inserimos os colchetes para ressaltar como o objeto a apressa a pressa, hathètise a hâte, operando como um objeto “(a)pressado” (PORGE, 1989/1994, p.116,156), sendo a queda do objeto a ligada à escansão significante que se estabelece em uma antecipação. Há uma temporalidade lógica que implica a escansão $S_{1}-S_{2}$, surgindo $\$$ e caindo a; eis os quatro termos que compõem a estrutura discursiva, como veremos adiante.

Antes, retomemos a articulação entre o mito da origem da civilização e o sofisma acerca do tempo lógico, enfatizando a estrutura temporal implicada no laço social. Nesse sentido, destacamos o subtítulo da última parte do artigo sobre o tempo lógico: “A verdade do sofisma como referência temporalizada de si para o outro: a asserção antecipatória como forma fundamental de uma lógica coletiva" (LACAN, 1945/1998, p.211, grifos nossos). Entendemos que a lógica coletiva pode ser referida ao próprio laço social, como a última nota do artigo parece coadunar, articulando o coletivo dessa lógica à psicologia coletiva que Freud explora em Psicologia das massas e a análise do eu. Uma das grandes contribuições do sofisma do tempo lógico ao tema do laço social é a possibilidade de pensá-lo a partir de uma lógica que decorre do efeito significante das escansões temporais. Destaca-se uma asserção antecipatória, ou seja, um juízo em ato marcado por determinada temporalidade, no fundamento do laço social.

Embora haja uma asserção de certeza antecipada, nem tudo no laço social se refere à dimensão de certeza. A certeza antecipada resulta da entrada em ação da dimensão temporal, que torna possível antecipar o destino final da via de acesso ao gozo do pai primevo — morte e despedaçamento do corpo — tornando esse gozo impossível por estrutura. Porém, tal certeza antecipada se produz sob um fundo de incerteza, pois o gozo do pai primevo segue como suposto, não experimentado. A certeza não se refere ao laço social, mas ao impossível que comporta tal posição de exceção, conduzindo à morte e despedaçamento 
do corpo. Ao lado da certeza, o laço social surge como aposta, possibilidade de se obter alguma satisfação, mesmo que não a do pai primevo. Como em toda aposta, há uma perda de saída, sendo a renúncia ao gozo condição a todo laço social possível. O encontro traumático com a linguagem pressupõe a perda de gozo e o ganho de significantes, sendo o laço social uma aposta de que se pode aparelhar discursivamente o gozo, promovendo algum tratamento ao trauma da linguagem. Mesmo sem garantias, uma vez feita a aposta, esta é irreversível.

O mito de Totem e tabu demarca a necessidade de uma renúncia de ordem pulsional para o estabelecimento de laço social, definindo um antagonismo entre gozo e laço social. Essa lógica permanece inatacável, mas não encerra toda a questão entre gozo e laço social, que se amplia a partir da concepção do objeto a e, sobretudo, da teoria lacaniana dos discursos, na qual não somente o significante participa, mas também o próprio sujeito como dividido, $\$$, e um resto de gozo, a. É preciso renunciar ao gozo para estabelecer laço social, mas o próprio laço social é permeado de gozo.

\section{OS QUATRO DISCURSOS E O CAPITALISTA}

A fórmula dos quatro discursos (LACAN, 1969-1970/1992) parte de uma estrutura fixa de lugares e operadores, a partir dos quais quatro termos, $S_{1}, S_{2}$, a e $\$$ - sempre mantida essa ordem - realizam um quarto de giro gerando uma nova modalidade discursiva. À exceção do lugar da verdade, os lugares recebem mais de um nome ao longo do ensino de Lacan, destacando-se, primeiramente, duas montagens:

$$
\frac{\text { agente }}{\text { verdade }} \longrightarrow \frac{\text { trabalho }}{\text { produção }} \quad \frac{\text { desejo }}{\text { verdade }} \longrightarrow \frac{\text { Outro }}{\text { perda }}
$$

Além dos termos e lugares, há operadores essenciais na estrutura: as barras, as setas e a barreira. Há a barra do recalque, a impossibilidade no nível superior (p.166) e a barreira da impotência no nível inferior (p.101):

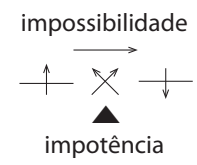

Em qualquer dos quatro discursos, o $\mathrm{S}_{1}$ permanece apartado do $\mathrm{S}_{2}$, seja pela barra, pelo impossível ou pela impotência. A escansão significante se mantém, garantindo o sujeito dividido, $\mathbf{S}$, como efeito dessa articulação significante em cadeia, bem como o resto de gozo que cai nesse intervalo, objeto a. Esse ponto será retomado adiante, ao tratarmos do matema do discurso do capitalista, no qual essa escansão temporal fica em questão. 
O aparelhamento discursivo do gozo tem no discurso do mestre sua forma inaugural e canônica, modalidade discursiva instaurada com a superação da horda primeva, tal como proposto pelo "mito científico" freudiano (FREUD, 1921/2011, p.101) acerca da origem do laço social. Supomos neste mito uma ilustração do próprio encontro com a linguagem, da incidência significante que produz o sujeito como dividido e inscrito no laço social. Assim, articulamos a fórmula lacaniana do discurso do mestre ao paradigma que se instaura a partir da superação da horda primeva, evento fundador do laço social:

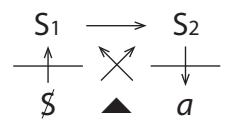

A renúncia após a eliminação do pai primevo transforma a eliminação do líder que se tornara inimigo em parricídio, crime primordial fundador da civilização. Esse efeito retroativo advém de uma temporalidade lógica que se inaugura pela delimitação de um tempo para compreender entre o instante do olhar e o momento de concluir, pela ação de uma escansão temporal operando de modo significante. Instaura-se a própria cadeia significante, isto é, se “[...] por meio do crime, está no poder do homem liberar a natureza das correntes [chaînes] de suas próprias leis [...]” (LACAN, 1959-1960/1991, p.315, colchete nosso), é a partir da transformação da eliminação do líder da horda em crime, parricídio, que se instaura a cadeia (chaîne) significante. A articulação significante depende da renúncia ao gozo por parte dos sobreviventes, $\$$, junto aos quais o objeto a passa a operar como testemunha do gozo perdido, incitando práticas de recuperação (LACAN, 1968-1969/2008, p.113), mantendo o aparelho discursivo em funcionamento. A montagem do discurso do mestre ilustra o funcionamento do inconsciente (LACAN, 1969-1970/1992, p.85). A partir do discurso do mestre os quartos de giro produzem as demais modalidades.

Os impactos discursivos do advento do capitalismo são abordados por Lacan em diferentes momentos. Ao indicar que a realidade capitalista não se dá nada mal com a ciência (LACAN, 1968-1969/2008, p.38), Lacan delimita sua primeira abordagem dos efeitos do capitalismo no discurso a partir da aliança indissociável entre a ciência moderna e o capitalismo. Há uma curiosa copulação (LACAN, 1969-1970/1992, p.103) que ocasiona uma “[...] mutação capital, também ela, que confere ao discurso do mestre seu estilo capitalista.” (p.160). A mutação capital se refere ao giro discursivo que produz o discurso universitário:

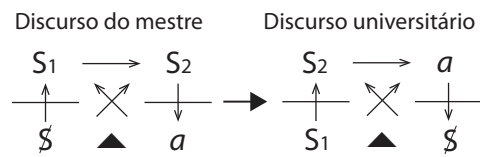


Entre a formulação do discurso universitário e sua associação ao capitalismo, e o matema do discurso do capitalista em 1972, Lacan indica que "Uma coisinha de nada que gira e o discurso do mestre de vocês mostra-se tudo o que há de mais transformável no discurso do capitalista." (LACAN, 1971/2009, p.47, grifo nosso). No início de 1972, Lacan aponta que a partir de um ínfimo deslizamento o discurso do mestre se torna o discurso do capitalismo (LACAN, 1971-1972/2011, p.88), até que, apenas quatro meses depois, Lacan escreve o matema do discurso do capitalista em uma conferência em Milão:

Discurso do capitalista

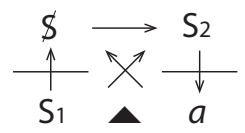

Essa fórmula opera como um hapax legomenon ${ }^{1}$ — termo que tem somente uma única aparição em uma língua - no ensino de Lacan, como ressaltam Carlos Faig (2000) e Néstor Braunstein (2010), não sendo retomado por Lacan após essa conferência. Por outro lado, as menções à teoria dos discursos também diminuem significativamente a partir da visada mais topológica empreendida por Lacan em seu ensino. Com isso, não há como afirmar se a coisinha de nada que gira e o ínfimo deslizamento descrevem o giro do discurso do mestre ao discurso universitário, ou a inversão de lugares entre $S_{1}$ e $\$$ no lado esquerdo do discurso do mestre que gera o discurso do capitalista. De qualquer forma, apostamos que a exploração de tal matema seja recompensadora na exploração dos efeitos do capitalismo no laço social, destacando os efeitos na temporalidade lógica em jogo no laço social.

O discurso do capitalista propõe um funcionamento que opera sem tropeços, de modo circular e sem corte, sem ponto de basta, ou seja, sem escansão. O que toca diretamente o tema que nos propomos a explorar é a ligação que se estabelece entre $S_{1}$ e $S_{2}$. No discurso do mestre a articulação $S_{1}$ e $S_{2}$ ocupa o nível do impossível, ficando estabelecido que um significante jamais representa plenamente o sujeito junto a outro significante. Dessa forma, o significante-mestre no lugar de agente comanda o saber ao trabalho, mas há uma perda nesse processo, algo que escapa à trama significante, a, que, enquanto mais-de-gozar, funciona como entropia no sistema, como a produção de uma perda irrecuperável. O interessante na maquinaria discursiva é que ela — diferente de uma máquina qualquer não fica indiferente à perda, buscando recuperação. É a esse funcionamento que Lacan concede estatuto de laço social.

Assim, o próprio estatuto discursivo do discurso do capitalista é questionável, na medida em que ele apresenta um funcionamento sem perdas, que

\footnotetext{
${ }^{1}$ Agradecemos a Cláudio Oliveira por essa interessante indicação.
} 
gira sobre si mesmo, colocando em xeque uma questão central ao laço social, a necessidade de renúncia ao gozo. Mesmo que a promessa de forclusão da castração (LACAN, 1971-1972/2011) sustentada pelo discurso capitalista não se cumpra, isso não significa que ela não tenha efeitos discursivos. O fracasso da promessa realimenta o funcionamento do sistema, deslocando metonimicamente para o próximo objeto de consumo a possibilidade de satisfação da promessa, capturando o sujeito - como consumidor - na trama do mercado, justificando as denominações de interminável e desmedido que Marx atribui ao modo de produção capitalista (MARX, 1867/2013, p.227-8). Esse fechamento em si mesmo, com um funcionamento circular, sem corte, é o que leva Lacan a afirmar que é por seu sucesso que uma crise se instala, estando o que de mais astucioso já se produziu como discurso voué à crevaison, fadado ao colapso, já que “[...] isso não tem como andar melhor, mas justamente isso anda rápido demais, isso se consome, isso se consome tão bem que isso se consuma" (LACAN, 1972/1978, p.48, tradução livre $^{2}$ e grifo nosso). A aceleração de todos os processos em jogo é patente no capitalismo. Essa temporalidade sem escansão, que introduz uma relação compulsiva de consumo com o objeto, é ressaltada pelo termo crevaison, que em francês é utilizado, por exemplo, quando um pneu estoura por excesso de ar. Não é por acaso que Lacan se serve desse termo, que indica uma explosão, implosão como efeito do excesso que opera como causa — mais-valor — , mas que não se perde, sendo continuamente contabilizado e reinvestido no sistema. Tal funcionamento relembra a descrição de Freud em Além do princípio do prazer (1920) acerca dos sistemas de seres unicelulares que se reproduzem eternamente, contanto que sejam retirados seus "produtos do metabolismo" (p.218), restos de seu funcionamento, sob pena de conduzi-los à degradação e à morte. O discurso do capitalista tenta operar sem produzir entropia, como se fosse possível evitar todas as perdas, o que pode levá-lo à consumição.

Marx descreve o processo de produção do capital no Livro I d’O capital, dedicando o Livro II ao processo de circulação do capital, já que a soma do tempo de produção e de circulação do capital configura a rotação do capital, que volta a ser investido no sistema, visando valorizar-se ainda mais, isto é, produzir mais-valor. A produção gera a mercadoria "fertilizada de mais-valor" (MARX, 1885/2014, p.120), mas para que a rotação se complete é preciso que a mercadoria, "prenhe de mais-valor" (p.110), seja vendida, sendo o consumo a sala de parto para que o mais-valor se realize ao capitalista, que deve reinvesti-lo o quanto antes, iniciando um novo ciclo. Configura-se um "movimento cíclico que se fecha em si mesmo” (p.135), movimento que tem repulsa a qualquer interrupção que comprometa sua continuidade.

\footnotetext{
2 “[...] ça ne peut pas marcher mieux, mais justement ça marche trop vite, ça se consomme, ça se consomme si bien que ça se consume."
} 
O consumo é o que realiza o mais-valor ao capitalista, logo, deve ocorrer o mais rápido possível. A mercadoria na prateleira é a encarnação de mais-valor imobilizado, fonte de horror ao capitalista, que anseia pelo retorno de sua prole - gerada pelo proletário, mas pertencente ao capitalista — , não para aninhá-la em seu bolso ou gastá-la em consumo próprio, mas para reinvesti-la na compra das mercadorias consumidas no processo de produção, meios de produção e força de trabalho, mercadoria "peculiar”, única capaz de fertilizar a mercadoria com mais-valor (MARX, 1867/2013, p.245). Tudo aquilo que torne o consumo mais lento é tido como um mal a ser extirpado.

“[...] a mais-valia, é a causa do desejo do qual uma economia faz seu princípio: o da produção extensiva, portanto insaciável, da falta-de-gozar [manque-à-jouir]. Esta se acumula, por um lado, para aumentar os meios dessa produção como capital. Por outro lado, amplia o consumo, sem o qual essa produção seria inútil, justamente por sua inépcia para proporcionar um gozo com que possa tornar-se mais lenta. (LACAN, 1970/2003, p.434, grifo nosso).

A estrutura produtiva capitalista depende da maximização da extração de mais-valor. Quanto mais tempo uma mercadoria leva para ser produzida, entrar no mercado e ser consumida, menor o mais-valor produzido, realizado e reinvestido. Logo, a dimensão temporal está implicada tanto na produção da mercadoria, quanto na velocidade de seu consumo. Cumpre localizar melhor a questão que nos toca. Decerto que a aceleração dos processos implica uma redução cronológica de cada etapa, em sua duração, mas não é essa dimensão temporal que mais nos interessa. O que buscamos destacar é que tal aceleração possui um correlato lógico, estrutural, podemos até dizer, discursivo.

Reencontramos a questão de como chegar à renúncia de gozo necessária ao laço social, com nossa hipótese acerca de uma condição de ordem temporal para tal, a saber, a interposição de uma escansão temporal, a instauração de um tempo para compreender que se precipite no momento de concluir pela renúncia de gozo. Assim, impasses tendem a surgir ao laço social no discurso do capitalista, na medida em que o tempo para compreender passa a ser tomado enquanto um vilão, que, caso não possa ser extirpado, ao menos deva ser reduzido ao máximo, afinal, time is money. Quanto menor for o tempo para compreender das decisões em jogo, mais veloz será a realização do mais-valor criado na mercadoria pelo trabalho e bem como o seu reinvestimento.

O tempo para compreender se torna um inimigo a ser combatido, pois gera um tropeço na máquina. Todos os quatro discursos funcionam com esse tropeço, ao passo que o discurso do capitalista tenta evitá-lo, sendo essa sua astúcia. A circularidade e a prevalência da metonímia em detrimento da metáfora são 
índices da tentativa de elisão do tempo para compreender, da escansão significante que promove o surgimento do sujeito dividido e do resto inassimilável ao significante. O mais-valor não opera como resto, sendo capturado, contabilizado em um sistema que pretende operar sem perdas. O gozo não deve mais ser adiado, sendo oferecido imediatamente pela via do consumo, das "latusas" (LACAN, 1969-1970/1992, p.153-4) que povoam as vitrines e telas, objetos que encarnam o valor de troca travestidos de um valor de uso maquiado como uma necessidade urgente. Contudo, algo escapa tanto ao valor de uso quanto ao valor de troca, um gozo que não se deixa apreender, que resta como impossível, inacessível, deixando o consumidor frustrado e relançando a promessa: nada de tempo para compreender, que venha o novo lançamento!

A promessa capitalista é a de gozo imediato e ilimitado, contanto que se tenha poder aquisitivo para tal, pois o preço se apresenta como um limite. Produz-se uma nova relação ao tempo, a do "tudo, tudo imediatamente" (ANSERMET, 2011, p.2), um tempo fora do tempo, eterno presente que captura como instante do olhar, com cada vez menos tempo para compreender o momento de concluir.

A promessa capitalista de forclusão da castração se ancora no consumo, na mercadoria, mas também se refere à temporalidade lógica em jogo no laço social: "O que a Verwerfung da castração rejeita é o tempo de constituição de um sujeito dividido que possa lançar uma questão fantasmática. Time is money é a máxima" (BECKER, 2004, p.137). Esse funcionamento que visa eliminar a escansão aproximaria a temporalidade lógica do discurso do capitalista da holófrase? Um consumidor imerso na debilidade, que não desperdiça tempo para compreender, seria o sujeito ideal do capitalismo? São questões que se abrem à futura investigação.

De qualquer forma, a psicanálise não desconsidera o tropeço, ela parte dele, e isso por entender que a perda é inevitável, que sempre resta algo que não se captura nem no significante, nem no valor - seja de uso, seja de troca. A promessa capitalista de forclusão da castração não se sustenta, restando o gosto amargo do mal-estar, mesmo que logo surja no mercado um novo remédio que prometa aplacá-lo. Ao analista diante de um sujeito capturado nessa promessa, enredado em um funcionamento que rechaça o corte, resta como direção de trabalho "[...] reintroduzir a escansão do tempo do sujeito, reintroduzir a escansão do tempo, a de um tempo lógico, mais do que a de um tempo que é feito apenas de um instante que gira, acelerado sobre si mesmo. Seja como for, para sair disso, é preciso passar pelo corte" (ANSERMET, 2011, p.5). A escansão pode advir do manejo do tempo variável da sessão - que subverte a lógica capitalista de $\mathrm{x}$ de tempo $=\mathrm{y}$ de dinheiro - , da interpretação que opera como corte na cadeia significante abrindo para novas significações, ou mesmo para o não sentido, impossível mesmo de significantizar, da recusa ao atendimento 
imediato das demandas do sujeito, enfim, de tudo aquilo que possa constituir um ato analítico. Os recursos são conhecidos, mas a invenção se impõe, pois não se deve esquecer que é na singularidade do caso a caso que se pode lançar mão daquilo que se revele capaz de operar um corte no funcionamento enredado por uma promessa se operar discursivamente sem perdas, mas que retorna como sofrimento, como mal-estar. Os efeitos de um ato analítico só se fazem conhecer a posteriori, trata-se sempre de uma aposta, e ao analista caberia saber que em toda aposta a perda é de início. Sem pressa por resultados, mas com a ética do corte nas mãos.

Recebido em 16/1/2015. Aprovado em 14/12/2015.

\section{REFERÊNCIAS}

ANSERMET, François. (2011) “Tudo imediatamente", in Correio n.70 Revista da Escola Brasileira de Psicanálise. Dezembro. Disponível em: http:// www.congresoamp.com/pt/Papers/Papers-002.pdf.

BECKER, Paulo. (2004) "A escrita do furo”, in A psicanálise e os discursos. Rio de Janeiro: Escola Letra Freudiana.

BRAUNSTEIN, Néstor. (2010) O discurso capitalista: quinto discurso? O discurso dos mercados (pst): sexto discurso? A escrita do furo, in A Peste, v.2, n.1, jan/jun. São Paulo: Educ, p.143-165.

FAIG, Carlos. (2000) El discurso del capitalista. Um hapax, in Imago agenda, n.45. Disponível em: http://www.imagoagenda.com/articulo. asp?idarticulo $=1689$.

FREUD, Sigmund. (2012) Obras completas. São Paulo: Companhia das Letras. (1912-13) “Totem e tabu”, v.11, p.14-244.

(1920) “Além do princípio do prazer”, v.14, p.161-239.

(1921) "Psicologia das massas e análise do Eu”, v.15, p.14-113.

LACAN, Jacques. (1945/1998) "O tempo lógico e a asserção de certeza antecipada”, in Escritos. Rio de Janeiro: Jorge Zahar Editor, p.197-213. (1959-1960/1991) O Seminário, livro 7: A ética da psicanálise. Rio de Janeiro: Jorge Zahar Editor.

(1968-1969/2008) O Seminário, livro 16: De um Outro ao outro. Rio de Janeiro: Jorge Zahar Editor.

(1969-1970/1992) O Seminário, livro 17: O avesso da psicanálise. Rio de Janeiro: Jorge Zahar Editor.

(1970/2003) "Radiofonia”, in Outros escritos. Rio de Janeiro: Jorge Zahar Editor. p.400-447.

(1971/2009) O Seminário, livro 18: de um discurso que não fosse semblante.

Rio de Janeiro: Jorge Zahar Editor.

(1971-1972/2011) Estou falando com as paredes: conversas na Capela de Sainte-Anne. Rio de Janeiro: Jorge Zahar Editor. 
(1972-1973/1985) O Seminário, livro 20: Mais, ainda. Rio de Janeiro: Jorge Zahar Editor.

(1972/1978) "Du discours psychanalytique", in Lacan in Itália. Milão: La Salamandra, p.32-55.

MALCHER, Fabio \& FREIRE, Ana Beatriz. (2013) Laço social na psicose: impasses e possibilidades. Ágora: estudos em teoria psicanalítica, v.XVI, n.1, jan/jul. Rio de Janeiro: Contra Capa, p.119-133.

MARX, Karl. (1867/2013) O capital: Crítica da economia política. Livro I: O processo de produção do capital. São Paulo: Boitempo.

. (1885/2014) O Capital: Crítica da economia política. Livro II: O processo de circulação do capital. São Paulo: Boitempo.

PORGE, Erik. (1989/1994) Psicanálise e tempo: o tempo lógico de Lacan. Rio de Janeiro: Campo Matêmico.

Fabio Malcher

fabiomalcher.rj@gmail.com

Ana Beatriz Freire

freireanab@hotmail.com 